\title{
Evaluation of Available Educational Resources for Early Childhood Education in Rivers State, Nigeria
}

\author{
Chinyere Catherine Ukala \\ University of Port Harcourt, Nigeria
}

\begin{abstract}
This study evaluated the availability of educational resources for early childhood education in Rivers State, Nigeria. Analytical survey design was used to provide relevant information for the research questions and two hypotheses posed. Through stratified random sampling technique, the head teachers of early childhood education centers from 165 public and 87 approved private primary schools comprised the research subjects. The instrument (EAERECEQ) was administered to all the head teachers of the mentioned centers. The data gathered using the instrument was organized and analyzed using mean, frequencies, ratio, standard deviation and t-test at 0.05 significant level. Findings revealed among others that instructional resources in form of charts and toys are grossly inadequate in public schools but moderately adequate in private schools. There is adequate supply of teachers and minders in both public and private schools, even though this supply is significantly more adequate for public schools. Unfortunately, these personnel were neither trained nor exposed to early childhood pedagogy. Based on the findings, some recommendations were made.
\end{abstract}

\section{Introduction}

Educational resources include human and material resources. [6] sees Educational resources as the sources from which institutional benefits are produced, which include: instructional materials, energy, services, staff, knowledge, or other assets that are transformed to produce educational benefits in the society. The human resources are the teaching and non-teaching staff. Instructional resources include among others school facilities, instructional materials, instructional aides, time and finance. Availability of these resources in schools aids the achievement of educational goals and objectives. Human resources in the school system are set of individuals that transmit knowledge necessary for individual and societal development into the learners. Human resources in education (teachers) impart knowledge or attempt to help someone acquire certain skills, attitude and knowledge through desirable changes in the behavior of students.
Instructional resources are resources the teacher uses to make their lesson concrete and factual in such a way to create pictures in the minds of the learners, also make the lesson more interesting and understandable to the learners. Instructional resource refers to the totality of non-human resources that is to be used for the attainment of educational goals [1]. These can also be referred to as the infrastructural facilities and finance available for use by the human resource within the school system. Instructional resources are the main contributors to teaching and students' learning outcomes in the school system [2]. Instructional resources include: educational facilities, instructional materials and finance, which involve school buildings, classrooms, furniture, libraries, recreational equipment, apparatus and other instructional materials [6]. Hence, there is need for them to be adequately provided in the school system.

The National Policy on Education stipulates that for effective handling of children in the school system, the teacher-pupil ratio should be 1:25 for the early childhood education [4]. This is a standard basis for determining teacher and other personnel requirement in these schools. [5] stated that underestimation of school enrolment and inability to determine in advance resource requirement is one of the reasons for the failure of previous UPE schemes to get the required number of qualified teaching manpower for its implementation. In agreement with this, [3] suggested that the (UBE) must begin a proper implementation programme by carrying out a realistic teacher requirement estimate.

Theoretically, [9] noted that the demand for teachers for preprimary education, just like any other level of education, will continue to be determined by demographic fluctuations, shifts in curricular emphases (from Arts to Science subjects) and alterations in policies related to teacher education. They agree with [9] that teacher retirement and attrition, increasing immigration, decreasing enrolment in teacher training institutions, will continue to increase the number of pupils/students and decrease pupil-teacher ratios, and thus the need for more teachers. Although these analyses reflect the situation in advanced societies; it is a pointer to what we should expect in developing societies. 
The inadequacy of qualified teachers for school enrollment ranges from poor professional status of teachers to even lack of fresh recruitment to fill empty vacancies [7]. [8] agreed with the above view as they asserted that there are not enough qualified teachers in Nigeria; and that this has negative outcomes, not only for the future of individual children, but also for the development of the society.

Shortage of qualified teachers and other school system staff like minders, nurses and other care givers in the educational system has become the main challenge to the realization of the goals of the UBE. Some of the reasons given for the dearth of teachers in the educational system include dissatisfaction with loss in status, low salaries, poor conditions of service, lack of career progression, poor training and re-training schemes [7]. These conditions in many cases have driven large number of teachers out of the profession, sometimes after only a few years of service; resulting to brain drain and high attrition rate. Most of the teachers now in the system are young, inexperienced, insufficiently trained, teachers lacking the necessary qualities for membership or role modeling [7].

Various published scholars have highlighted that the failure of previous projects has been due to the use of untrained and inadequately qualified teachers and in some cases lowering the entry levels of teacher training institution amongst other factors which subsequently reduced the quality of educational standards. All these have jeopardized the quality of education delivery which has resulted to poor standard of educational provision.

\section{Statement of the Problem}

In response to the above development, government of Rivers State, Nigeria through the UBE Board is now incorporating early childhood education programme into the UBE school programme. The researcher, just like many interested parents, is curious whether these centers housing early childhood education have the resource availability to implement this programme successfully as identified above. It is not even known what the level of resource availability is in private schools that have been providing this level of education. This is the problem which this study seeks to address.

\section{Aim and Objective of the Study}

The aim of this study is to evaluate the availability of educational resources for early childhood education programmers in Rivers State.

Specifically, the objectives of this study are to;

- Evaluate the availability of instructional resources in both public and private schools for the provision of early childhood education in Rivers State.
- Ascertain the ways teachers utilize the available instructional in early childhood centres in Rivers State.

- Evaluate the availability of human resources in terms of teachers and minders for the provision of early childhood education.

\subsection{Research Question}

1. What are the instructional resource availability for the provision of early childhood education in public and private schools in Rivers State?

2. How do teachers utilize the available instructional in early childhood centres in Rivers State?

3. What is the human resource availability for the provision of early childhood education in public and private schools in Rivers State?

\section{Hypotheses}

The following hypotheses were tested at 0.05alpha level.

1. There is no significant difference between public and private schools on the instructional resources availability for the provision of early childhood education in River State.

2. There is no significant difference between the mean scores of staff in public and private schools on the ways teachers utilize the available instructional in early childhood centres in Rivers State.

3. There is no significant difference between public and private schools on the human resources availability for the provision of early childhood education in River State.

\section{Methodology}

This is an analytical survey. The population consisted of 655 public and 271 approved private schools with early childhood centers spread across the 23 L.G.A. of Rivers State. A stratified random sampling technique was used in sampling $50 \%$ of the L.G.A.'s (giving 12 L.G.As.) and 50\% of public and private primary schools with early childhood education centers in the sample giving a total of 165 public and 87 approved private schools respectively (165 public and 87 private head-teachers).

Evaluation of Available Educational Resources for Early Childhood Education Questionnaire" (EAERECEQ) was adopted and modified with some relevant items from "school system diagnostics instrument". The data generated using this instrument was organized and analyzed using mean, ratio, frequencies, standard deviation. $\mathrm{z}$-test and $\mathrm{t}$ test were used to test the hypotheses at 0.05 significant levels. The instrument was administered personally by the researcher with the assistance of some primary school head-teachers who were sufficiently briefed for the assignment. 
Table 1. Frequency and Percentage Distribution of Public and Private Early Childhood schools by their Instructional Resource Availability

\begin{tabular}{|c|c|c|c|c|c|c|}
\hline \multirow[t]{2}{*}{$\mathbf{S} / \mathbf{N}$} & \multirow[t]{2}{*}{$\begin{array}{l}\text { Instructional } \\
\text { Resources }\end{array}$} & \multirow[t]{2}{*}{ Standard Specifications } & \multicolumn{2}{|c|}{$\begin{array}{c}\text { Schools with Standard } \\
\text { Facilities }\end{array}$} & \multicolumn{2}{|c|}{$\begin{array}{c}\% \text { of Schools with } \\
\text { Standard Facilities }\end{array}$} \\
\hline & & & 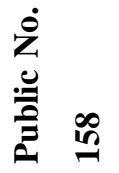 & 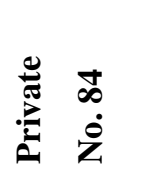 & $\frac{\mathscr{U}}{3}$ & $\sum_{\substack{\pi\\
}}^{0}$ \\
\hline 1. & Library & $\begin{array}{l}\text { Classroom size well stocked } \\
\text { library }\end{array}$ & 16 & 63 & 10.1 & 75.0 \\
\hline 2. & $\begin{array}{l}\text { Library corners in } \\
\text { classrooms }\end{array}$ & $\begin{array}{l}\text { Well stocked library corners } \\
\text { in the class }\end{array}$ & 16 & 52 & 10.1 & 61.9 \\
\hline 3. & $\begin{array}{l}\text { In-door play } \\
\text { toys/teaching aids }\end{array}$ & $\begin{array}{l}\text { Like building blocks, gig- saw } \\
\text { puzzles, books with copious } \\
\text { local illustrations, wall charts, } \\
\text { etc. in varieties of shapes and } \\
\text { colours }\end{array}$ & 21 & 72 & 13.3 & 85.7 \\
\hline & Aggregate Mean & & & & 11.2 & 74.2 \\
\hline
\end{tabular}

\section{Results and Discussion}

1. What are the instructional resources availability for the provision of early childhood education in public and private schools in Rivers State?

The findings revealed that, the proportions of public schools that have these facilities to meet their enrolment are $10.1 \%$ for library and library corners in the classrooms and $13.3 \%$ for indoor play toys and teaching aids. The private schools on the other hand have very high instructional resource availability, which is represented by $75 \%, 61.9 \%$ and $85.7 \%$ respectively for library, stocked library corners and indoor play toys and teaching aids. This high differential is evident by a mean instructional resource availability of $11.2 \%$ for public schools and $74.2 \%$ for private schools.
The general development of this level of education are met through large and comprehensive unit of materials of instruction that would simultaneously stimulate psychomotor and cognitive development, teach team work, basic knowledge and skills, and integrate psychological and cognitive development. As a matter of fact, preschool environment, classroom and provision of instructional materials are essential to meaningful interaction. The educational setting must be conducive enough to facilitate children's' interaction with the environment that enables them to acquire knowledge and look for solution outside the box.

2. How do teachers utilize the available instructional resources in early childhood centres in Rivers State?

Table 2. Mean scores and standard deviation of head-teachers on the ways teachers utilize the available instructional resources in early childhood centres in Rivers State

\begin{tabular}{|c|c|c|c|c|c|c|c|}
\hline \multirow[t]{2}{*}{$\mathbf{S} / \mathbf{N}$} & \multirow[t]{2}{*}{$\begin{array}{l}\text { Ways teachers utilize the available instructional } \\
\text { resources in early childhood centres include: }\end{array}$} & \multicolumn{2}{|c|}{$\begin{array}{l}\text { Public school } \\
\text { head-teachers }\end{array}$} & \multicolumn{2}{|c|}{$\begin{array}{l}\text { Private school } \\
\text { head-teachers }\end{array}$} & \multirow[t]{2}{*}{$\begin{array}{l}\text { Mean } \\
\text { Set }\end{array}$} & \multirow[t]{2}{*}{$\begin{array}{l}\text { Rank } \\
\text { Order }\end{array}$} \\
\hline & & $\bar{X}_{\mathbf{1}}$ & St.D & $X_{2}$ & St.D & & \\
\hline 1 & $\begin{array}{l}\text { Teachers relate instructional resources to the } \\
\text { topic of the lesson }\end{array}$ & 3.08 & 0.32 & 3.02 & 0.41 & 3.05 & 7th \\
\hline 2 & $\begin{array}{l}\text { Using the resources within the age level of } \\
\text { learners }\end{array}$ & 3.12 & 0.32 & 3.16 & 0.39 & 3.14 & 4 th \\
\hline 3 & $\begin{array}{l}\text { They arrange the resources to stimulate growth in } \\
\text { factual knowledge/literary appreciation }\end{array}$ & 3.03 & 0.32 & 3.01 & 0.41 & 3.02 & 8 th \\
\hline 4 & $\begin{array}{l}\text { They use the resources to stimulate aesthetic } \\
\text { values/societal standards }\end{array}$ & 3.18 & 0.31 & 3.06 & 0.41 & 3.12 & 5 th \\
\hline 5 & $\begin{array}{l}\text { They design the resources to support the general } \\
\text { educational goals }\end{array}$ & 3.19 & 0.31 & 3.21 & 0.38 & 3.20 & 2nd \\
\hline
\end{tabular}




\begin{tabular}{llllllll}
\hline 6 & $\begin{array}{l}\text { Make the resources appropriate for social } \\
\text { development of the child }\end{array}$ & 3.26 & 0.30 & 3.16 & 0.39 & 3.21 & 1 st \\
7 & $\begin{array}{l}\text { Design the resources to motivate students } \\
\text { examine their own attitudes/behaviour }\end{array}$ & 3.21 & 0.30 & 3.09 & 0.40 & 3.15 & 3 rd \\
8 & 3.11 & 0.32 & 3.01 & 0.41 & 3.06 & 6 th \\
\hline $\begin{array}{l}\text { Create resources to stimulate the operational } \\
\text { definition of subject contents }\end{array}$ & $\mathbf{3 . 1 5}$ & $\mathbf{0 . 3 1 3}$ & $\mathbf{3 . 0 9}$ & $\mathbf{0 . 4 0 0}$ & $\mathbf{3 . 1 2}$ & \\
\hline Aggregate mean & & &
\end{tabular}

Data on table 2 present the mean scores and standard deviation of head-teachers on the ways teachers utilize the available instructional resources in early childhood centres in Rivers State. Both public and private head-teachers agreed on all the items in the table with mean scores greater than the mean criterion of 2.50 ranging from $1^{\text {st }}$ to $8^{\text {th }}$. The aggregate mean score 3.12 showed that, the ways teachers utilize the available instructional resources in early childhood centres in Rivers State include: relating instructional resources to the topic of the lesson, using the resources within the age level of learners, arranging the resources to stimulate growth in factual knowledge/literary appreciation, using the resources to stimulate aesthetic values/ societal standards, designing the resources to support the general educational goals, making the resources appropriate for social development of the child, designing the resources to motivate students examine their own attitudes/behaviour, and creating resources to stimulate the operational definition of subject contents.

3. What is the human resource availability for the provision of early childhood education in public and private schools in River State?

Table 3. Analysis of Teacher Availability and Satisfied Capacity Rates for Early Childhood Education in Public and Private Schools

\begin{tabular}{|c|c|c|c|c|c|c|c|c|}
\hline \multirow{2}{*}{$\begin{array}{l}\text { LGAs } \\
\text { 1. AbualOdual }\end{array}$} & \multicolumn{2}{|c|}{ No. of Schools } & \multicolumn{2}{|c|}{$\begin{array}{c}\text { Existing } \\
\text { Enrollment }\end{array}$} & \multicolumn{2}{|c|}{$\begin{array}{c}\text { Teachers } \\
\text { Availability }\end{array}$} & \multicolumn{2}{|c|}{$\begin{array}{c}\text { Satisfied Available } \\
\text { Rates }\end{array}$} \\
\hline & 14 & 3 & 1278 & 310 & 34 & 8 & 66.5 & 64.5 \\
\hline 2. Degema & 12 & 4 & 1438 & 352 & 48 & 9 & 83.4 & 85.2 \\
\hline 3. Eleme & 10 & 5 & 814 & 412 & 27 & 11 & 82.9 & 66.8 \\
\hline 4. Emohua & 7 & 3 & 633 & 278 & 19 & 7 & 75.0 & 62.9 \\
\hline 5. Etche & 16 & 6 & 1593 & 415 & 41 & 12 & 64.3 & 72.3 \\
\hline 6. Ikwerre & 15 & 5 & 1725 & 752 & 58 & 19 & 84.1 & 63.2 \\
\hline 7. Kana & 13 & 3 & 1067 & 432 & 35 & 7 & 82.0 & 40.5 \\
\hline 8. Obio/Akpor & 18 & 17 & 1125 & 2145 & 40 & 77 & 88.9 & 89.7 \\
\hline 9. Ogba/Egbema/Ndoni & 15 & 8 & 1048 & 684 & 37 & 20 & 88.3 & 73.1 \\
\hline 10. Okrika & 9 & 4 & 495 & 374 & 18 & 8 & 90.9 & 53.5 \\
\hline 11. Oyigbo & 10 & 7 & 876 & 1124 & 30 & 20 & 85.7 & 44.5 \\
\hline 12. Port Harcourt & 19 & 19 & 855 & 2414 & 34 & 91 & 99.4 & 90.1 \\
\hline Aggregate & 158 & 84 & 12947 & 9692 & 421 & 286 & 82.6 & 67.2 \\
\hline
\end{tabular}

This question assessed the human resource availability, for both private and public schools to provide early childhood education in terms of availability of teachers and minders to cope with the existing enrolment in the light of the minimum standard specification. To address this question, the researcher collected enrolment statistics as well as staffing list for the sampled schools in the twelve sampled LGAs. The result of the data analysis is presented in Tables 3 and 4.

The teacher availability for early childhood was judged on the minimum standard specification of 25 pupils per class. Table 3 shows the number of schools sampled, existing school enrolment at this level and the teacher satisfied availability rate in twelve sampled LGAs. The satisfied availability rates here (expressed in percentage) are the ratios of existing teachers available to actual capacity needed to meet the minimum standard specification based on existing enrolment.

From the evidence in Table 2, public schools have high teacher availability for early childhood education centers. This is because public schools satisfied between $66.5 \%$ and $99.4 \%$ of needed teachers, with an average of $82.6 \%$ for the sampled LGAs.

Private schools on the other hand have moderately high teacher availability rates, as they are meeting up between $40.5 \%$ and $90.1 \%$ of their teacher demand, with an average of $67.2 \%$ for the 12 sampled LGAs.

As clearly shown in Figure 1, teacher availability rate is generally higher for public schools, except for Degema, Etche and Obio/Akpor LGAs. The differences between public and private schools are also more outstanding for Ikwerre, Khana, Okrika 
and Oyigbo LGAs. Minders are teaching support staff in the early childhood unit. Minimum standard

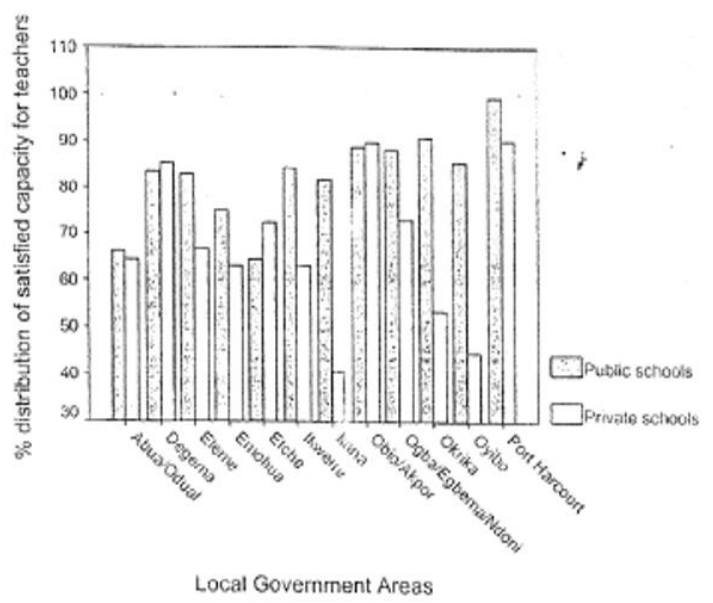

Figure 1. teacher availability rate

both public and private schools to provide adequate minders to meet this minimum standard regulation was also carried out and the result is presented in Table 4.

The evidence in Table 4 clearly shows that while public schools have excess minders in relation to their early childhood pupil enrolment, the private schools are barely meeting up half of their needed minders for their existing enrolment. This is so, since public schools in eight out of the twelve LGAs have exceeded their needed minder capacity (i.e. above 100\%) with none of the remaining LGAs meeting below $90 \%$ availability (with an aggregate mean of 113.10). Private schools on the other hand are only meeting between $48.38 \%$ to $67.32 \%$ of their minimum requirement for minders, with an average of $54.84 \%$ across the twelve sampled LGAs. This evidence shows a widening gap between public and private schools in favour of public schools. The numerical availability of teachers and minders is a vital but not an adequate parameter for assessing the human resources availability of early childhood centers. This is because these personnel are expected to have some minimum level of professional training in early childhood education pedagogy at the National Certificate in Education (NCE) level. The researcher therefore examined the quality of these teachers and minders in terms of their professional qualification and training. A summary of that assessment is presented in Table 4.

From table 5, it can be observed that public schools have very high number of qualified teachers with minimum of NCE $(95.72 \%)$ with moderate numbers $(50.83 \%)$ trained in early childhood pedagogy and very insignificant number with exposure to retraining in Montessori method. They however have very low number of qualified minders $(20.42 \%)$, minders with training in early childhood pedagogy (13.6 1\%), teachers exposed to training $(5.22 \%)$ and none at all for minders. specification demands that there should be a minder in each classroom. A survey of the availability of

The private schools on the other hand have moderate number of qualified teachers $(65.73 \%)$ and low number of qualified minders.Personneltraining in early childhood education in private school is $(42.66 \%)$ and minders $(23.11 \%)$. They have moderate number of teachers with exposure to Montessori retraining programme $(67.31 \%)$ and for minders (56.44).

The findings of this study revealed that the staffing availability for the provision of early childhood education in public schools is adequate to meet the minimum standard specification with regard to teachers and minders (average of 82\%), but virtually nill for doctors, nurses and guidance counselors. Although teachers are well qualified, most of them and virtually all the minders lack training in early childhood education. Private schools have moderately adequate teachers but inadequate minders to meet the minimum standard (average of 63\%) but most of the teachers do not possess the minimum qualification of NCE, even though most of them are regularly exposed to retraining programme.

HO1: There is no significant difference between public and private schools in the instructional resource availability for the provision of early childhood education in River State.

Table 6 shows that the T-value comparing mean instructional resources availability of public and private schools is -10.472 , which is significant at 0.009 . Since it is lower than the 0.05 alpha level at which the hypothesis was tested, we conclude that the difference is significant. A look at the two means in Table 5 shows that the mean private school (74.20) is by far higher than those of public school (11.17). This means that private schools have significantly higher instructional resources availability than public schools. Therefore, the null hypothesis is rejected.

$\mathrm{HO}_{2}$ : There is no significant difference between the mean scores of staff in public and private schools on the ways teachers utilize the available instructional in early childhood centres in Rivers State

Data on Table 7 show the analysis of z-test on the difference between the mean scores of staff in public and private schools on the ways teachers utilize the available instructional resources in early childhood centres in Rivers State. The z-calculated value of 1.210 is less than the $\mathrm{z}$-critical value of \pm 1.960 at 0.05 alpha significant level and 250 degree of freedom, indicating that the null hypothesis was accepted. This means that, there is no significant difference between the mean scores of staff in public and private schools on the ways teachers utilize the available instructional in early childhood centres in Rivers State. 
Table 4. Analysis of Minder Availability and Satisfied Capacity Rates for Early Childhood Education in Public and Private Schools

\begin{tabular}{|c|c|c|c|c|c|c|c|c|}
\hline \multirow[t]{2}{*}{ LGAs } & \multicolumn{2}{|c|}{ No. of Schools } & \multicolumn{2}{|c|}{$\begin{array}{c}\text { Existing } \\
\text { Enrollment }\end{array}$} & \multicolumn{2}{|c|}{$\begin{array}{c}\text { Minder } \\
\text { Availability }\end{array}$} & \multicolumn{2}{|c|}{$\begin{array}{c}\text { Satisfied Available } \\
\text { Rates }\end{array}$} \\
\hline & $\frac{\ddots}{3}$ & 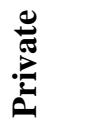 & $\frac{.}{3}$ & 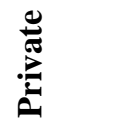 & 关 & 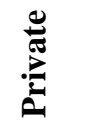 & 关 & 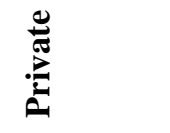 \\
\hline 1. AbualOdual & 14 & 3 & 1278 & 310 & 46 & 6 & 89.98 & 48.38 \\
\hline 2. Degema & 12 & 4 & 1438 & 352 & 52 & 8 & 90.40 & 56.82 \\
\hline 3. Eleme & 10 & 5 & 814 & 412 & 38 & 8 & 116.7 & 48.54 \\
\hline 4. Emohua & 7 & 3 & 633 & 278 & 30 & 6 & 118.5 & 54.0 \\
\hline 5. Etche & 16 & 6 & 1593 & 415 & 63 & 9 & 98.90 & 54.22 \\
\hline 6. Ikwerre & 15 & 5 & 1725 & 752 & 75 & 14 & 108.7 & 46.54 \\
\hline 7. Kana & 13 & 3 & 1067 & 432 & 50 & 9 & 117.2 & 52.08 \\
\hline 8. Obio/Akpor & 18 & 17 & 1125 & 2145 & 58 & 48 & 128.9 & 55.94 \\
\hline 9. Ogba/Egbema/Ndoni & 15 & 8 & 1048 & 684 & 40 & 16 & 126.3 & 58.48 \\
\hline 10. Okrika & 9 & 4 & 495 & 374 & 25 & 8 & 128.4 & 53.48 \\
\hline 11. Oyigbo & 10 & 7 & 876 & 1124 & 45 & 28 & 137.4 & 62.27 \\
\hline 12. Port Harcourt & 19 & 19 & 855 & 2414 & 47 & 65 & 113.1 & 67.32 \\
\hline Aggregate & 158 & 84 & 12947 & 9692 & 529 & 225 & 114.54 & $\mathbf{5 4 . 8 4}$ \\
\hline
\end{tabular}

Table 5. Frequency and Percentage Distribution of Teachers and Minders by Professional Qualification and Training in Public and Private Early Childhood schools

\begin{tabular}{|l|l|l|l|l|l|l|}
\hline S/N & Personnel Quality Indices & \multicolumn{2}{c|}{$\begin{array}{c}\text { Staff } \\
\text { Category }\end{array}$} & \multicolumn{2}{c|}{ Frequency } & \multicolumn{2}{c|}{ \% } \\
\cline { 3 - 7 } & & & Public & Private & Public & Private \\
\hline 1. & Personnel with at least NCE as & Classroom teachers & 403 & 188 & 95.72 & 65.73 \\
\cline { 3 - 7 } & qualification & Minders & 108 & 42 & 20.42 & 18.67 \\
\hline 2. & $\begin{array}{l}\text { Personnel trained in early } \\
\text { childhoodEducation/care }\end{array}$ & Classroom teachers & 214 & 122 & 50.83 & 42.66 \\
\cline { 3 - 7 } & Minders & 72 & 52 & 13.61 & 23.11 \\
\hline 3. & $\begin{array}{l}\text { Personnel exposed to regular } \\
\text { Montessoriretraining }\end{array}$ & Classroom teachers & 22 & 192 & 5.22 & 67.13 \\
\cline { 3 - 7 } & Minders & - & 127 & 0 & 56.44 \\
\hline
\end{tabular}

Table 6. Mean, SD and T-Test of Difference Between Public and Private Schools in the Instructional Resources Availability for the Provision of Early Childhood Education

\begin{tabular}{|l|l|l|l|c|c|c|}
\hline S/N & \multicolumn{1}{|c|}{ Categories } & \multicolumn{1}{|c|}{$\mathbf{N}$} & \multicolumn{1}{|c|}{ Mean } & T-value & 2-Tailed (Sig. Value) & \multicolumn{1}{|c|}{ Remarks } \\
\hline 1. & Public schools & 12 & 11.17 & \multirow{2}{*}{-10.472} & .009 & Significant \\
\hline 2. & Private schools & 12 & 74.20 & & \\
\hline
\end{tabular}


Table 7. Analysis of z-test on the difference between the mean scores of staff in public and private schools on the ways teachers utilize the available instructional in early childhood centres in Rivers State

\begin{tabular}{|c|c|c|c|c|c|c|c|c|}
\hline $\mathbf{S} / \mathbf{N}$ & $\begin{array}{c}\text { Categories of Head- } \\
\text { Teachers }\end{array}$ & $\mathbf{N}$ & Mean & St.D & Df & $\begin{array}{l}\text { z-calculated } \\
\text { value }\end{array}$ & $\begin{array}{l}\text { z-Critical } \\
\text { Value }\end{array}$ & Remarks \\
\hline 1. & Public schools & 165 & 3.15 & 0.313 & & & & \\
\hline 2. & Private schools & 87 & 3.09 & 0.400 & 250 & 1.210 & \pm 1.96 & Accepted \\
\hline
\end{tabular}

Table 8. Mean and T-Test of Difference between Public and Private Schools in Human Resource Availability (Teaching Staff) for the Provision of Early Childhood Education

\begin{tabular}{|c|c|c|c|c|c|c|}
\hline $\mathbf{S} / \mathbf{N}$ & Staffing availability indices & \multicolumn{2}{|c|}{$\begin{array}{c}\text { Mean } \\
\text { Availability } \\
\text { Performance }\end{array}$} & 竞 & 离 & 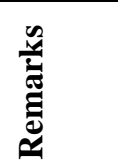 \\
\hline 1. & Teachers satisfied capacity rates & 82.62 & 67.19 & 3.135 & .009 & Sig. \\
\hline 2. & Minders satisfied capacity rate & 113.07 & 54.82 & 13.784 & .000 & Sign. \\
\hline 3. & Teachers/minders quality index & 31.00 & 45.62 & -974 & .375 & Not sig. \\
\hline
\end{tabular}

HO$_{3}$ : There is no significant difference between public and private schools in the human resources availability for the provision of early childhood education in River State.

As clearly shown in Table 8, the comparison of the first two staffing availability indices produced TValues of 3.135 which are significant at .009 for teachers' satisfied availability rate and 13.784 which are significant at .000 for minders' satisfied availability rate. Since these two levels of significance are by far less than 0.05 alpha level. The researcher considered the differences as significant. The hypothesis is therefore rejected for these two variables. The comparison of personnel quality is therefore rejected for these two variables. The comparison of personnel quality index on the other hand yield no significant difference. This is because they obtained T-Value of -974 was found significant at 0.375 , which is by far higher than 0.05 alpha level.

A comparison of the mean of teachers and minders available rate shows that those of public schools are higher than those of private schools. This means that public schools have significantly higher availability for teachers and minders than private schools.

\section{Conclusion}

From these results, it is very evident that both public and private schools do not have adequate educational resources for early childhood education. Even though the availability of human resources in terms of teachers and minders may seem adequate, unfortunately, these personnel were neither trained nor conversant with early childhood pedagogy. As a result, the successful implementation of early childhood education will be a mirage considering that these vital resources are inadequate.

\section{Recommendations}

1. Now that government have shown interest on early childhood education, it is vital for government to make early childhood a comprehensive programme that should be collaborated with medical; paramedical, educationist, parents and members of the community and equip this level of education that is capital intensive in qualitative and quantitative dimension.

2. Government should mount centers for training and re-training of teachers for this level of education.

3. Government needs to review the minimum standards for early childhood education, which must receive input from educational planners, curriculum developers and other professionals of early childhood level of education. Besides defining the minimum standard, government must take the bold step by complying and enforcing these guidelines. This can be achieved by ensuring that all the public early childhood education centers are fully equipped with all the necessary instructional and qualified human resources that would give a sound educational foundation for the development of the Nigerian child. Such a practical standard should be the justifiable benchmark for monitoring and inspection of early childhood education centers. Detailed guidelines must be available to all proprietors of private schools and Head of Schools that house early childhood education centers.

4. Government should make it mandatory for all teacher training institutions to mount early 
childhood education programmes for training of teachers for this level of education and enforce regular inspection and supervision of these schools to ensure compliance with the minimum standard and quality delivery.

Finally, the diversified economic, social and political demand on education leave a country with no choice but to invest in building the whole structure of knowledge and skills. This can only be done by investing holistically in building the whole pyramid of knowledge and skills. With this approach, each level in the structure has its own importance and should not be traded for another.

\section{References}

[1] R. A. Adeboyeje, Maintenance of School Plant. A Case Study of College of Education. In D. U. Adereoummu, and S. O. Jiboyea (eds.). Reflections on Nigerian Education: A Book of Readings. Ife: University of Ife Press (2002).

[2] L. Adeyanju, (2003). Teachers perception of the effects and use of learning aids in teaching: A Case Study of Winneba Basic and Secondary Schools in Ghana. UltiBASE. Retrieved from: http://ultibase.rmit.edu.au. (Access Date: July 4, 2015)

[3] R. O. A. Aluede, Universal Basic Education in Nigeria: Matters arising. Nigerian Journal of Curriculum and Instruction, 20(2), (2006), p.97-101

[4] Federal Republic of Nigeria, (2013). National Policy on Education (6th ed.). Abuja: NERDC.

[5] Maduagwu, S. N., Administration of Universal Basic Education: The basic facts. Owerri: Springfield publishers Ltd (2006).

[6] Nwabueze, A. I., Resources in education. In J.M. Ebong, J. D. Asodike \& N. J. Izuagba (Eds.) Economics of Education: Expository Issues (p. 186-205). Port Harcourt: EagleLithograph Publishers (2016).

[7] Okeke, B. S. Politics of education: The Nigerian Experience. Awka: Doone Printing \& publishing (2007).

[8] UNESCO and ILO, Status of teacher's quality in Nigeria. The Vanguard, Lagos, Thursday 25 October 2007, p. 33 (2007).

[9] Monk, D. and Plecki, M., School Finance and Teacher Quality: Exploring the connection centre for education policy analysis, Stratford (2003). 